\title{
Plasmid associated virulence properties of environmental isolates of Aeromonas hydrophila
}

\author{
J. J. BORREGO, M. A. MORIÑIGO, E. MARTINEZ-MANZANARES, M. BOSCA, \\ DOLORES CASTRO, J. L. BARJA* and ALICIA E. TORANZO* $\dagger$ \\ Department of Microbiology, Faculty of Sciences, University of Malaga, 29071-Malaga and "Department of \\ Microbiology and Parasitology, Faculty of Biology, University of Santiago, 15706-Santiago de Compostela. Spain
}

\begin{abstract}
Summary. The plasmid profiles, and their association with antimicrobial resistance, of 60 strains of Aeromonas hydrophila isolated from fish, shellfish and water were investigated. Only two strains were susceptible to all the antimicrobial agents tested; the highest incidences of resistance were to tetracycline $(96.7 \%)$, prystanamycin $(93.3 \%)$, ampicillin $(91.7 \%)$ and cephalothin $(91.7 \%)$. Forty strains harboured one or more plasmids and the plasmid profile most frequently detected $(15 \%)$ was the association of three small plasmids of $4 \cdot 2,3 \cdot 2$ and 2.8 Mda. Curing experiments indicated that the plasmid-free derivative strains simultaneously lost their resistance determinants to tobramycin, neomycin, gentamicin and kanamycin. More than $90 \%$ of the strains tested produced siderophores and displayed haemolytic activity. However, the relationship between these virulence characters and the presence of plasmids was different; in $74.5 \%$ of the strains there was siderophore production and plasmids were detectable, whereas only $60 \%$ of the strains simultaneously possessed plasmids and haemolytic activity.
\end{abstract}

\section{Introduction}

Aeromonas hydrophila causes several diseases among poecilotherms and warm blood animals, including haemorrhagic septicaemia, red sore, gastroenteritis and endocarditis. ${ }^{1-4}$ In recent years, the increased development of the aquaculture of fish and shellfish has exacerbated the problems of infections of these animals caused by different pathogenic micro-organisms. In addition, the extensive use of chemotherapeutic agents in fish farms, as feed additives or administered into the water to prevent and treat fish diseases, has resulted in an increase of drug-resistant bacteria. $^{5}$

Several bacterial phenotypic properties, such as antimicrobial resistance or virulence factors, have been demonstrated to be plasmid encoded. The presence of plasmids in these potentially pathogenic micro-organisms may present a potential public health hazard, because they may be transferred from animals to man either directly of indirectly. ${ }^{5,6}$

Several reports have shown that the presence of plasmids in clinically important bacteria increases their virulence. ${ }^{7-10}$ Various virulence factors of Vibrio and Aeromonas spp. have been characterised, including extracellular products and protein molecules of the cell envelope. ${ }^{11-14}$ One of the most important factors involved in the virulence of the pathogenic strains is

Received 2 Nov. 1990; accepted 30 Jan. 1991.

+ Correspondence should be sent to Prof. A. E. Toranzo. the possession of an efficient iron-sequestering system mediated by siderophores, ${ }^{15,16}$ which allows the bacteria to grow in the iron-limiting conditions imposed by the high-affinity iron-binding proteins present in organic fluids. ${ }^{9,16,17}$

In this study the antimocrobial resistance, the presence of haemolytic activity and the production of diffusible siderophores by $A$. hydrophila strains isolated from water and animals (shellfish and fish) were examined and the relationships between these virulence factors and the plasmid profiles of the strains were identified.

\section{Materials and methods}

\section{Bacterial strains and culture conditions}

Sixty strains of $A$. hydrophila isolated from animals (shellfish and fish) and water (freshwater and seawater) samples were used in this study. Stock cultures were maintained frozen at $-20^{\circ} \mathrm{C}$ in Glycerol $15 \% \mathrm{v} / \mathrm{v}$ Tryptic Soy Broth (TSB; Difco) and, before electrophoretic analysis, were grown in Brain-Heart Infusion Broth (BHIB; Difco) incubated at $28^{\circ} \mathrm{C}$ for $24-36 \mathrm{~h}$.

\section{Antimicrobial susceptibility}

Resistance of the isolates to antimicrobial agents was determined by a disk diffusion method on MuellerHinton Agar (MHA; BioMerieux), with disks containing $(\mu \mathrm{g})$ : amikacin 30 , ampicillin 10, carbenicillin 100 , 
cephalothin 30, chloramphenicol 30 , colistin 10 , gentamicin 10, kanamycin 30, nalidixic acid 30 , neomycin 30, nitrofurantoin 300 , polymyxin B $300 \mathrm{U}$, prystanamycin 15 , streptomycin 10 , sulphadiazine 1000, sulphamethoxazole-trimethoprim (co-trimoxazole) $1 \cdot 25-23 \cdot 75$, tetracycline 30 , and tobramycin 10 . All the antibiotic disks and criteria for resistance were supplied by BioMerieux.

\section{Plasmid detection by agarose gel electrophoresis}

Plasmid DNA was isolated from small volumes (3$4 \mathrm{ml}$ ) of bacterial cultures, by the method of Kado and Liu ${ }^{18}$ with several modifications. ${ }^{19}$ Briefly, cultures in exponential growth phase were centrifuged for $3 \mathrm{~min}$ at $12000 \mathrm{~g}$. Cell pellets were resuspended in $50 \mu \mathrm{l}$ of lysis solution (SDS $3 \%$ in $50 \mathrm{~mm}$ Tris, $\mathrm{pH} \mathrm{12.4)} \mathrm{and}$ incubated at $55-60^{\circ} \mathrm{C}$ for $45 \mathrm{~min}$, after which the plasmid DNA was extracted with an equal volume of phenol-chloroform solution $(1: 1, \mathrm{v}: \mathrm{v})$. The emulsion was separated by centrifugation for $10 \mathrm{~min}$ at $12000 \mathrm{~g}$. The aqueous phase was removed and mixed with tracking dye solution (bromocresol purple $0.25 \%$ glycerol $50 \%$ in Tris-acetate buffer). DNA samples $(20 \mu \mathrm{l})$ were separated by horizontal electrophoresis in an agarose $0.7 \%$ gel (type I; Sigma) in Tris-acetate buffer ( $40 \mathrm{~mm}$ Tris, $2 \mathrm{~mm}$ sodium acetate adjusted to $\mathrm{pH} 7.9$ with glacial acetic acid) at $150 \mathrm{~V}, 110 \mathrm{~mA}$ for $5 \mathrm{~h}$. The gels were stained in ethidium bromide solution $0.5 \mu \mathrm{g} / \mathrm{ml}$, and photographed through a UV transilluminator with Plus X-Pan film and 23A Wratten filter.

Reference plasmids from Escherichia coli V517 (35.8-1.4 Mda) and E. coli R40a (96 Mda) were included as markers in the agarose gel electrophoresis.

\section{Haemolytic activity}

$\beta$-Haemolytic isolates were identified on blood agarBlood Agar Base (BAB; Difco) and washed sheep erythrocytes $5 \%$. Haemolysin production was recorded as clearance of the medium around the growth after $24 \mathrm{~h}$ at $25^{\circ} \mathrm{C}$.

\section{Growth under iron-limiting conditions and production of siderophores}

A. hydrophila strains were cultured in M9 minimal medium ${ }^{20}$ supplemented with Casamino Acids (Difco) $0.2 \% \mathrm{w} / \mathrm{v}$. The iron chelator ethylenediamine-di- $(o-$ hydroxyphenyl acetic acid) (EDDA) was added at a concentration of $10 \mu \mathrm{M}$ to achieve the iron limited conditions.

The production of siderophore compounds by the strains was tested on blue agar plates as described by Schwyn and Neilands. ${ }^{21}$ The method is based on the fact that the dye chrome-azurol S (Sigma), incorporated in the medium, can form stable complexes with iron. Therefore, when a strain produces a diffusible siderophore (which removes the iron from the com- plex) the colour turns to yellow-orange around the colony after $24-48 \mathrm{~h}$ at $25^{\circ} \mathrm{C}$.

\section{Curing experiments}

Curing experiments with acridine orange (Sigma), were done by a modification of the techniques described by Winkler et al. ${ }^{22}$ Cells were grown in BHIB for $24 \mathrm{~h}$, and $2 \mathrm{ml}$ samples were added to $1 \mathrm{ml}$ of fresh broth and incubated for $3 \mathrm{~h}$ at $26^{\circ} \mathrm{C}$. Then, $1 \mathrm{ml}$ of a solution of Acridine Orange (Sigma) $20 \mu \mathrm{g}$ / $\mathrm{ml}$ was added, and the culture was centrifuged at $3500 \mathrm{~g}$ for $20 \mathrm{~min}$. The supernate was removed and $2 \mathrm{ml}$ of fresh BHIB was added to the pellet and incubated at $26^{\circ} \mathrm{C}$ for $2-6 \mathrm{~h}$. After this time, the strains were tested for loss of drug resistance, siderophore and haemolytic activities, and plasmid content.

\section{Results}

\section{Antimicrobial susceptibility of $A$. hydrophila strains}

Sixty strains of $\boldsymbol{A}$. hydrophila from animals (shellfish and fish), freshwater and seawater sources were examined for resistance to 18 antimicrobial substances. The overall percentage of drug-resistance (table I) indicated that $>90 \%$ of the strains were resistant to ampicillin $(91.7 \%)$, cephalothin $(91.7 \%)$, tetracycline $(96.7 \%)$ and prystanamycin $(93.3 \%)$, whereas $<10 \%$ were resistant for amikacin $(0 \%)$, gentamicin $(3.3 \%)$, neomycin $(5 \%)$ and polymyxin B $(8.3 \%)$.

Although the proportion of all strains that were resistant was quite similar, some differences was found according to the source of isolation (table I). Indeed, resistance to gentamicin was detected only amongst strains isolated from seawater. Similarly, higher percentages of resistance to carbenicillin, chloramphenicol, co-trimoxazole and nalidixic acid were obtained with strains isolated from water compared with those from strains of animal origin. For streptomycin, tobramycin, and kanamycin, the percentages of resistance obtained for the freshwater strains were significantly lower $(p<0.01)$ than for the other strains.

\section{Plasmid content of the A. hydrophila isolates}

Forty $A$. hydrophila strains $(66.7 \%$ of total) harboured one or more plasmids; 27 of them contained more than one plasmid. Small plasmids $(1 \cdot 1-19 \mathrm{Mda})$ were detected in 17 strains, and larger plasmids of $\geq 20 \mathrm{Mda}$ were detected in 13 strains. Ten strains harboured plasmids both of low and high mol. wt.

The number and mol. wt. of the plasmid bands detected in $A$. hydrophila strains are given in table II. The number of plasmid bands differed and depended on the source. From the freshwater environment strains with one, two, three, five and eight plasmids were detected; the highest number of plasmid bands 
Table I. Resistance to 18 antimicrobial agents of the strains of $A$. hydrophila from different sources before and after curing with acridine orange

\begin{tabular}{|c|c|c|c|c|c|c|c|c|}
\hline \multirow{3}{*}{$\begin{array}{l}\text { Antimicrobial } \\
\text { agent }\end{array}$} & \multicolumn{8}{|c|}{ Percentage of resistant strains from } \\
\hline & \multicolumn{2}{|c|}{ freshwater (23) } & \multicolumn{2}{|c|}{ seawater (27) } & \multicolumn{2}{|c|}{ animals (10) } & \multicolumn{2}{|c|}{ total $(60)$} \\
\hline & before & after & before & after & before & after & before & after \\
\hline Ampicillin (Am) & 86.9 & 86.9 & $92 \cdot 6$ & $92 \cdot 6$ & 100 & 100 & $91 \cdot 7$ & $91 \cdot 7$ \\
\hline Amikacin (AN) & 0 & 0 & 0 & 0 & 0 & 0 & 0 & 0 \\
\hline Carbenicillin (Cb) & $69 \cdot 6$ & $69 \cdot 6$ & $74 \cdot 1$ & $74 \cdot 1$ & 10 & 10 & $61 \cdot 7$ & $61 \cdot 7$ \\
\hline Cephalothin (Cf) & 86.9 & 86.9 & 92.6 & 92.6 & 100 & 100 & $91 \cdot 7$ & $91 \cdot 7$ \\
\hline Chloramphenicol (C) & $65 \cdot 2$ & $52 \cdot 2$ & $51 \cdot 9$ & $48 \cdot 1$ & 20 & 20 & $51 \cdot 7$ & $45 \cdot 0$ \\
\hline Colistin $(\mathrm{Cl})$ & $26 \cdot 1$ & $21 \cdot 7$ & $18 \cdot 5$ & $14 \cdot 8$ & 20 & 0 & $21 \cdot 7$ & $15 \cdot 0$ \\
\hline Gentamicin $(\mathrm{Gm})$ & 0 & 0 & $7 \cdot 4$ & 0 & 0 & 0 & $3 \cdot 3$ & 0 \\
\hline Kanamycin (K) & $4 \cdot 3$ & 0 & $18 \cdot 5$ & 0 & 10 & 0 & $11 \cdot 7$ & 0 \\
\hline Nalidixic acid (NA) & $60 \cdot 9$ & $34 \cdot 8$ & $59 \cdot 3$ & $44 \cdot 4$ & 10 & 10 & $51 \cdot 7$ & $33 \cdot 3$ \\
\hline Neomycin (N) & $4 \cdot 3$ & 0 & $3 \cdot 7$ & 0 & 10 & 0 & $5 \cdot 0$ & 0 \\
\hline Nitrofurantoin (FM) & $78 \cdot 3$ & $78 \cdot 3$ & $81 \cdot 5$ & $81 \cdot 5$ & 60 & 60 & $76 \cdot 7$ & $76 \cdot 7$ \\
\hline Polymyxin B (PB) & $4 \cdot 3$ & $4 \cdot 3$ & $11 \cdot 1$ & $11 \cdot 1$ & 10 & 10 & $8 \cdot 3$ & $8 \cdot 3$ \\
\hline Prystanamycin (Pr) & $86 \cdot 9$ & $86 \cdot 9$ & $96 \cdot 3$ & $96 \cdot 3$ & 100 & 100 & $93 \cdot 3$ & $93 \cdot 3$ \\
\hline Streptomycin (S) & $43 \cdot 5$ & $8 \cdot 7$ & $85 \cdot 2$ & $55 \cdot 6$ & 80 & 20 & $68 \cdot 3$ & $31 \cdot 7$ \\
\hline Sulphadiazine (Sd) & $78 \cdot 3$ & $13 \cdot 0$ & $74 \cdot 1$ & $18 \cdot 5$ & 60 & 0 & $73 \cdot 3$ & $13 \cdot 3$ \\
\hline Co-trimoxazole (SXT) & $69 \cdot 6$ & $8 \cdot 7$ & $63 \cdot 0$ & $37 \cdot 0$ & 30 & 20 & $60 \cdot 0$ & $23 \cdot 3$ \\
\hline Tetracycline (Te) & 95.6 & $95 \cdot 6$ & $96 \cdot 3$ & $96 \cdot 3$ & 100 & 100 & $96 \cdot 7$ & 96.7 \\
\hline Tobramycin (NN) & $8 \cdot 7$ & 0 & $11 \cdot 1$ & 0 & 20 & 0 & $11 \cdot 7$ & 0 \\
\hline
\end{tabular}

Table II. Number and mol. wt of the plasmids from $A$. hydrophila strains

\begin{tabular}{|c|c|c|c|}
\hline Source & $\begin{array}{l}\text { Strain } \\
\text { no. }\end{array}$ & Plasmid sizes (Mda) & Antimicrobial resistance* \\
\hline Freshwater & $\begin{array}{l}\text { R158 } \\
\text { R9 } \\
\text { R11 } \\
\text { R19, R21 } \\
\text { R12 } \\
\text { R24 } \\
\text { R23 } \\
\text { R26 } \\
\text { R107 } \\
\text { R27 } \\
\text { R106, R161 } \\
\text { R105, R174 } \\
\text { R102 } \\
\text { R97 }\end{array}$ & $\begin{array}{l}100 \\
86 \\
28 \\
25 \\
1 \cdot 1 \\
25,14 \\
7 \cdot 2,4 \cdot 2,3 \cdot 4 \\
4 \cdot 2,3 \cdot 2,2 \cdot 8 \\
4 \cdot 2,3 \cdot 2,2 \cdot 8 \\
3 \cdot 4,2 \cdot 8,2 \cdot 5 \\
3 \cdot 4,2 \cdot 8,2 \cdot 5 \\
123,60,3 \cdot 2,2 \cdot 8,2 \cdot 5 \\
100,74,6 \cdot 5,4 \cdot 2,3 \cdot 4 \\
86,49,42,34,11,8 \cdot 1, \\
4 \cdot 8,3 \cdot 2\end{array}$ & $\begin{array}{l}\text { Am,Cb,Cf,Te,Pr,FM,S,C,Sd,SXT,NA } \\
\text { Am,Cb,Cf,Te,Pr,C,FM,S,Sd,SXT,NA } \\
\text { Am,Cb,Cf,Te,Cl,Pr,C,NA,FM,N,Sd,SXT } \\
\text { Am,Cb,Cf,Te,Cl,Pr,C,FM,Sd,SXT,NA } \\
\text { Am,Cb,Cf,Te,Pr,C,FM,Sd,SXT,NA } \\
\text { Am,Cb,Cf,Te,Pr,FM,C,SXT,NA } \\
\text { Am,Cb,Cf,Te,Pr,FM, } \overline{\text { Cl,C }} \\
\text { Am,Cb,Cf,Te,Pr,C,NA,FM,Sd,SXT } \\
\text { Am,Cb,Cf,Te,Pr,C,SXT,NA,FM,S,Sd } \\
\text { Am,Cb,Cf,S,Te,Cl,Pr,C,NA,FM,NN,Sd,SXT } \\
\text { Am,Cb,Cf,Pr,Te,NA,FM,S,Sd,SXT } \\
\text { Am,Cf,Te,Pr,NA,S,Sd,SXT } \\
\text { Am,Cf,S,Te,Pr,NN,Sd } \\
\text { Am,Cb,Cf,Te,Pr,C,NA,FM,S,K,Sd,SXT }\end{array}$ \\
\hline Seawater & $\begin{array}{l}\text { M137 } \\
\text { M118 } \\
\text { M134 } \\
\text { M117 } \\
\text { M181 } \\
\text { M92 } \\
\text { M91 } \\
\text { M87 } \\
\text { M186 } \\
\text { M116 } \\
\text { M86, M88 } \\
\text { M89 } \\
\text { M185 } \\
\text { M124 } \\
\text { M136 }\end{array}$ & $\begin{array}{l}34 \\
3 \cdot 2 \\
34,28 \\
30,13 \\
9 \cdot 5,4 \cdot 2 \\
74,4 \cdot 2,2 \cdot 8 \\
8 \cdot 6,4 \cdot 8,4 \cdot 2 \\
8 \cdot 6,3 \cdot 4,3 \cdot 2 \\
6 \cdot 5,3 \cdot 4,3 \cdot 2 \\
4 \cdot 2,3 \cdot 2,2 \cdot 8 \\
4 \cdot 2,3 \cdot 2,2 \cdot 8 \\
3 \cdot 4,2 \cdot 8,2 \cdot 5 \\
74,3 \cdot 4,2 \cdot 8,2 \cdot 5 \\
60,42,30,2 \cdot 5 \\
60,34,30,3 \cdot 4\end{array}$ & $\begin{array}{l}\text { Am,Cf,Te,Pr,S,K,Sd,SXT } \\
\text { Am,Cb,Cf,Te,Pr,NA,FM,S,Gm,NN,K,Sd,SXT } \\
\text { Am,Cb,Cf,Te,Pr,C,FM,Sd } \\
\text { Am,Cb,Cf,Te,Pr,C,NA,F,M,S,N,Gm,NN,Sd,SXT } \\
\text { Am,Cf,Te,Pr,FM,S,C,SXT,NA } \\
\text { Am,Cb,Cf,Te,Pr,C,SXT,NA,FM,S,Sd } \\
\text { Am,Cb,Cf,Te,Pr,NA,FM,S,Sd,SXT } \\
\text { Am,Cb,Cf,Te,Pr,C,NA,FM,S,Cl,Sd,SXT } \\
\text { Am,Cb,Cf,S,Te,Pr,C,FM,NN,K,Sd,SXT,NA } \\
\text { Am,Cb,Cf,Te,Pr,C,SXT, NA,FM,S,Sd } \\
\text { Am,Cb,Cf,S,Te,Pr,C,SXT,NA,FM,Sd } \\
\text { Am,Cb,Cf,Te,Pr,C,FM,Sd,NA } \\
\text { Am,Cb,Cf,S,Te,Pr,FM, } \\
\text { Am,Cb,Cf,S,Te,Pr,C,SXT,FM,Sd,NA } \\
\text { Am,Cb,Cf,S,NN,Te,Pr,C,SXT,NA,FM, }, \text { N,Sd }\end{array}$ \\
\hline Animals & $\begin{array}{l}\text { S296, S297 } \\
\text { S294 } \\
\text { S278, S295 } \\
\text { S85 } \\
\text { S263 }\end{array}$ & $\begin{array}{l}60 \\
55 \\
30 \\
86,45 \\
4 \cdot 2,3 \cdot 2,2 \cdot 8\end{array}$ & $\begin{array}{l}\text { Am,Cf,Te,Pr,S,NN,K,Cl,Sd } \\
\text { Am,Cf,Te,Pr,FM,S,N,Sd } \\
\text { Am,Cf,Te,Pr,C,SXT,NA,FM,S,Sd } \\
\text { Am,Cf,Te,Pr,FM,Sd } \\
\text { Am,Cf,Te,Pr,FM,S,SXT }\end{array}$ \\
\hline
\end{tabular}

* Underlining indicates loss of resistance after curing. For abbreviations, see table I. 
found in the strains from the other two sources was four. The mol. wt of the plasmids detected in freshwater strains varied between $1 \cdot 1$ and $123 \mathrm{Mda}$, although the small plasmids were more frequent $(64.7 \%)$. For the strains isolated from seawater and marine animals, the plasmid profiles were very similar; eight strains carried only large plasmids, 10 strains possessed only small plasmids and five strains carried both small and large plasmids. The plasmid profile most frequently detected was the association of three small plasmids of $4 \cdot 2,3 \cdot 2$ and $2 \cdot 8 \mathrm{Mda}(15 \%)$.

\section{Relationship between the presence of plasmids and antimicrobial resistance}

To establish the relationship between plasmids and antimicrobial resistance, the strains were divided into four groups according to their plasmid content: (1) plasmid-free strains; (2) strains that harboured only small plasmids; (3) strains that carried only large plasmids; and (4) strains with both small and large plasmids. The numbers of strains that were resistant to chemotherapeutic agents in each group are shown in table III. Regardless of the presence of plasmids, a high percentage of $A$. hydrophila strains were resistant to ampicillin, cephalothin, tetracycline and prystanamycin, which indicates that resistance to these antibiotics is chromosomal. However, the presence of plasmids in these strains seemed to increase their antimicrobial resistance. All the strains that were resistant to polymyxin $B$ were characterised by the absence of plasmids, demonstrating that this resistance may not be plasmid-encoded.

Resistance to gentamicin, kanamycin, neomycin and tobramycin must be mediated by plasmids in most

Table III. Relationship between the presence of plasmids and resistance to antimicrobial agents

\begin{tabular}{|c|c|c|c|c|}
\hline \multirow{2}{*}{$\begin{array}{l}\text { Antimicrobial } \\
\text { resistance } \\
\text { demonstrated }\end{array}$} & \multicolumn{4}{|c|}{ Number of strains } \\
\hline & $\begin{array}{c}\text { no } \\
\text { plasmid } \\
(20)\end{array}$ & $\begin{array}{c}\text { small } \\
\text { plasmids } \\
(17)\end{array}$ & $\begin{array}{c}\text { large } \\
\text { plasmids } \\
(13)\end{array}$ & $\begin{array}{l}\text { small and } \\
\text { large } \\
\text { plasmids } \\
(10)\end{array}$ \\
\hline Ampicillin & 15 & 17 & 13 & 10 \\
\hline Carbenicillin & 9 & 15 & 6 & 7 \\
\hline Cephalothin & 15 & 17 & 13 & 10 \\
\hline Chloramphenicol & 5 & 12 & 8 & 6 \\
\hline Colistin & 5 & 3 & 5 & $\mathbf{0}$ \\
\hline Gentamicin & 0 & 1 & 0 & 1 \\
\hline Kanamycin & 0 & 2 & 3 & 2 \\
\hline Nalidixic acid & 1 & 15 & 7 & 8 \\
\hline Neomycin & 0 & 0 & 2 & 1 \\
\hline Nitrofurantoin & 12 & 17 & 10 & 7 \\
\hline Polymyxin B & 5 & 0 & 0 & 0 \\
\hline Prystanamycin & 16 & 17 & 13 & 10 \\
\hline Streptomycin & 12 & 13 & 8 & 8 \\
\hline Sulphadiazine & 8 & 14 & 13 & 9 \\
\hline Co-trimoxazole & 5 & 15 & 8 & 8 \\
\hline Tetracycline & 18 & 17 & 13 & 10 \\
\hline Tobramycin & 0 & 3 & 2 & 2 \\
\hline
\end{tabular}

of the isolates, because these resistance determinants were not detected in plasmid-free strains. Whereas resistance to kanamycin and tobramycin was found in strains with small and large plasmids, resistance to neomycin and gentamicin seemed to be mediated by large and small-plasmids, respectively.

The number of strains resistant to nalidixic acid, co-trimoxazole, carbenicillin, nitrofurantoin and chloramphenicol and also possessing small plasmids, was significantly higher $(\mathrm{p}<0.1)$ than the number of strains belonging to other groups.

\section{Siderophore production and haemolytic activity}

The ability of the $A$. hydrophila strains to grow in iron-limited conditions and their haemolytic activity were tested to verify their role as putative virulence factors and to demonstrate their relationship with plasmid carriage. More than $75 \%$ of the strains tested gave an orange halo of 6-8 mm after incubation for $48 \mathrm{~h}$, and $<10 \%$ of the strains did not produce siderophore activity (table IV). Similarly, most of the strains $(>90 \%)$ were haemolytic. A higher number of isolates showing both siderophore and haemolytic activities were from seawater and animals than were from freshwater $(23.3 \%$ and $11.7 \%$ vs $6.7 \%$, respectively).

The relationship between siderophore production and plasmid content was consistent; $>74 \%$ of strains with siderophore activity possessed plasmids, although the percentage varied with the source (c. $85 \%$ of freshwater strains and $68 \%$ from seawater). The proportion of strains that were haemolytic and harboured plasmids was $c .60 \%$ (table IV).

\section{Curing experiments}

All the derivative isolates from acridine orange treatment were tested for plasmid content and antimicrobial resistance. The percentages of strains with antimicrobial resistance after curing are shown in table I. $A$. hydrophila strains isolated from the three environments carried resistance genes which are presumed to be located in the bacterial chromosome for ampicillin, cephalothin, tetracycline, carbenicillin, prystanamycin and nitrofurantoin. In contrast, the cured, plasmid-free strains lost, simultaneously, their resistance to tobramycin, neomycin, gentamicin and kanamycin (table II). Resistance to nalidixic acid, streptomycin, co-trimoxazole, sulphadiazine, chloramphenicol and colistin appeared to be linked to chromosomal and plasmid genes (table II). Whereas a high percentage $(61.3 \%)$ of strains lost their siderophore activity after curing, all the plasmid-free derivative isolates were haemolytic.

\section{Discussion}

The results showed that environmental and pathogenic $A$. hydrophila strains were naturally resistant to 
Table IV. Distribution of siderophore production and haemolytic activity among $A$. hydrophila strains

\begin{tabular}{lcccc}
\hline & \multicolumn{4}{c}{ Number $(\%)$ of strains with the property from } \\
\cline { 2 - 5 } \multicolumn{1}{l}{ Character } & freshwater & seawater & $\begin{array}{c}\text { animal } \\
\text { sources }\end{array}$ & Total \\
& & & & \\
\hline Siderophore production & $17(28 \cdot 3)$ & $21(35 \cdot 0)$ & $7(11 \cdot 7)$ & $45(75)$ \\
Plasmids and siderophore & $17(85 \cdot 0)$ & $17(68 \cdot 0)$ & $7(70 \cdot 0)$ & $41(74 \cdot 5)$ \\
Haemolysis & $19(82 \cdot 6)$ & $26(96 \cdot 3)$ & $10(100)$ & $55(91 \cdot 7)$ \\
Plasmids and haemolysis & $14(60 \cdot 9)$ & $15(55 \cdot 6)$ & $7(70)$ & $36(60)$ \\
Siderophores and haemolysis & $4(6 \cdot 7)$ & $14(23 \cdot 3)$ & $7(11 \cdot 7)$ & $25(41 \cdot 7)$ \\
Plasmids and both factors & $4(100)$ & $7(50 \cdot 0)$ & $6(85 \cdot 7)$ & $17(68 \cdot 0)$ \\
& & & & \\
\hline
\end{tabular}

ampicillin, cephalothin, tetracycline and prystanamycin, and susceptible to amikacin. These results are in agreement with those of other authors ${ }^{5,23-26}$ for ampicillin and cephalothin. However, Hayashi et al. ${ }^{27}$ and Hedges $e$ al. $^{28}$ suggested that the resistance of $A$. hydrophila strains to tetracycline was linked to several plasmids. In this study plasmids of 1.1-123 Mda were detected in the $A$. hydrophila strains (table II). Similar ranges were obtained by Toranzo et al. ${ }^{19}$ (1.6 and $28 \mathrm{Mda}$ ) and Hedges et al. ${ }^{28}$ ( 38 and $100 \mathrm{Mda}$ ) who examined strains of $A$. hydrophila from animal and human sources, respectively.

To establish the role of the plasmids on the antimicrobial resistance of $\boldsymbol{A}$. hydrophila, curing experiments with acridine orange were performed. The results indicated that the plasmid-free strains did not change in their antimicrobial resistance profiles (before and after curing) which indicates that the resistance determinants were not plasmid-borne and that the curing agent did not affect the chromosomal genes. However, it should be noted that, in some cases, nalidixic acid resistance determinants were lost during curing experiments. Nalidixic acid resistance has not previously been identified to be carried on a plasmid. These results suggest, but do not prove, that nalidixic acid resistance may be plasmid-borne in this species. In this study single or combined resistance to tobramycin, kanamycin, neomycin and gentamicin was always linked to plasmids and never appeared in plasmid-free strains. This finding is supported by the curing experiments in which loss of plasmids was accompanied by loss of resistance to these drugs. Similar results were obtained by Overman $e t a l^{25}$ and Daily et al. ${ }^{29}$

The relationship between the presence of plasmids and some pathogenic characters, such as enterotoxigenicity, haemolysin production or presence of surface antigens, have been studied mainly in the Enterobac-

\section{References}

1. Hazen TC, Raker ML, Esch GW, Fliermans CB. Ultrastructure of red-sore lesions on largemouth bass (Micropteru salmoides); association of the ciliate Epistylis sp. and the bacterium Aeromonas hydrophila. J Protozool 1978; 25 $351-355$.

2. Huizinga HW, Esch GW, Hazen TC. Histopathology of red- teriaceae. ${ }^{30-32}$ However, for other species, correlation between virulence factors and plasmid profiles have been reported in only a few instances. ${ }^{10,33,34}$ From the results obtained in this study, we conclude that there is a close relationship between the presence of plasmids and siderophore production, because $>70 \%$ of the siderophore producing strains also possessed plasmids. This conclusion is supported by the curing experiments in which the plasmid-free derivatives lost the ability to grow in iron-limiting conditions. These findings are similar to those reported for Vibrio anguillarum. ${ }^{7,15,35}$ However, c. $30 \%$ of the strains examined retained the iron-sequestering system after loss of plasmids. These results indicate that the genes coding for this system in A. hydrophila are located on both plasmid and chromosome. Similar conclusions were obtained by Valvano et al. ${ }^{36}$ who studied the aerobactin iron transport system in human invasive strains of $E$. coli $\mathrm{K} 1$, and by Lemos et al. ${ }^{17}$ in the anguibactin-mediated system of $V$. anguillarum.

The correlation between the virulence of $A$. hydrophila for fish, or its enterotoxigenicity, with the production of haemolysins, enterotoxins and cytotoxins is variable and contradictory. ${ }^{14,37,38}$ In the present study, haemolytic activity was more prevalent in strains isolated from animals $(100 \%)$ than in those from water $(c .80 \%)$. This property seems to be chromosome-encoded because plasmid-free strains maintained the haemolytic activity. The role of haemolysins in the pathogenicity of $\boldsymbol{A}$. hydrophila is difficult to establish. In our opinion, the haemolysins could increase the availability of iron for the microorganisms by erythrocyte lysis.

This work was supported by research grant no. AQ-018/84 from the Comisión Asesora de Investigación Científica, y Técnica, Ministerio de Educación y Ciencia (Spain) and a research grant from Acuerdo Diputación Provincial de Cádiz-Consejería de Agricultura y Pesca de la Junta de Andalucia (Spain). sore disease (Aeromonas hydrophila) in naturally and experimentally infected largemouth bass Micropterus salmoides (Lacépède). J Fish Dis 1979; 2: 263-277.

3. Joseph SW, Daily OP, Hunt WS, Seidler RJ, Allen DA, Colwell RR. Aeromonas primary wound infection of a diver in polluted waters. J Clin Microbiol 1979; 10: 46-49.

4. Ljungh $\AA$, Popoff M, Wadström T. Aeromonas hydrophila in acute diarrheal disease: detection of enterotoxin and biotyping of strains. J Clin Microbiol 1977; 6: 96-100. 
5. Toranzo AE, Combarro P, Lemos ML, Barja JL. Plasmid coding for transferable drug resistance in bacteria isolated from cultured rainbow trout. Appl Environ Microbiol 1984; 48: 872-877.

6. Aoki T, Arai T, Egusa S. Detection of R plasmids in naturally occurring fish-pathogenic bacteria, Edwardsiella tarda. Microbiol Immunol 1977; 21 : 77-83.

7. Crosa JH, Hodges LL, Schiewe MH. Curing of a plasmid is correlated with an attenuation of virulence in the marine fish pathogen Vibrio anguillarum. Infect Immun 1980; 27: 897-902.

8. Tolmasky ME, Actis LA, Toranzo AE, Barja JL, Crosa JH. Plasmids mediating iron uptake in Vibrio anguillarum strains isolated from turbot in Spain. J Gen Microbiol 1985 ; 131 : $1989-1997$.

9. Toranzo AE, Barja JL, Potter SA, Colwell RR, Hetrick FM, Crosa JH. Molecular factors associated with virulence of marine vibrios isolated from striped bass in Chesapeake Bay. Infect Immun 1983; 39; 1220-1227.

10. Toranzo AE, Santos $\mathrm{Y}$, Lemos ML, Ledo A, Bolinches J. Homology of Vibrio anguillarum strains causing epizootics in turbot, salmon and trout reared on the Atlantic Coast of Spain. Aquaculture 1987; 67:41-52.

11. Munn CB, Ishiguro EE, Kay WW, Trust TJ. Role of surface components in serum resistance of virulent Aeromonas salmonicida. Infect Immun 1982; 36: 1069-1075.

12. Nomura $S$, Saito $H$. Production of the extracellular hemolytic toxin by an isolated strain of Aeromonas salmonicida. Bull Japn Soc Sci Fish 1982; 48: 1589-1597.

13. Sakai DK. Electrostatic mechanism of survival of virulent Aeromonas salmonicida strains in river water. Appl Environ Microbiol 1986; 51: 1343-1349.

14. Santos Y, Toranzo AE, Barja JL, Nieto TP, Villa TG. Virulence properties and enterotoxin production of Aeromonas strains isolated from fish. Infect Immun 1988; 56: 3285-3293.

15. Crosa JH. A plasmid associated with virulence in the marine fish pathogen Vibrio anguillarum specifies and iron-sequestering system. Nature $1980 ; 284$ : 566-568.

16. Griffiths E. The iron-uptake systems of pathogenic bacteria In: Bullen JJ, Griffiths E (eds) Iron and infection. Chichester, John Wiley and Sons. 1987: 69-137.

17. Lemos ML, Salinas $\mathbf{P}$, Toranzo AE, Barja JL, Crosa JH. Chromosome-mediated iron uptake system in pathogenic strains of Vibrio anguillarum. J Bacteriol 1988; 170: 1920 1925.

18. Kado CI, Liu S-T. Rapid procedure for detection and isolation of large and small plasmids. $J$ Bacteriol 1981 ; 145: 13651373.

19. Toranzo AE, Barja JL, Colwell RR, Hetrick FM. Characterization of plasmids in bacterial fish pathogens. Infect Immun $1983 ; 39: 184-192$.

20. Miller JH. Experiments in molecular genetics. Cold Spring Harbor, NY, Cold Spring Harbor Laboratory. 1972.

21. Schwyn B, Neilands JB. Universal chemical assay for the detection and determination of siderophores. Anal Biochem $1987 ; 160: 47-56$
22. Winkler U, Rüger W, Wackernagel W. Bacterial, phage and molecular genetics. Berlin, Springer-Verlag. 1976: 127130.

23. Neilson AH. The occurrence of aeromonads in activated sludge : isolation of Aeromonas sobria and its possible confusion with Escherichia coli. J Appl Bacteriol 1978; 44: 259-264.

24. Nord C-E, Wadström T, Wretlind B. Antibiotic sensitivity of two Aeromonas and nine Pseudomonas species. Med Microbiol Immunol 1975; 161 : 89-97.

25. Overman TL, D'Amato RF, Tomfohrde KM. Incidence of "oxidase-variable" strains of Aeromonas hydrophila. J Clin Microbiol 1979; 9: 244-247.

26. Seidler RJ, Allen DA, Lockman H, Colwell RR, Joseph SW Daily OP. Isolation, enumeration, and characterization of Aeromonas from polluted waters encountered in diving operations. Appl Environ Microbiol 1980; 39: 1010-1018.

27. Hayashi F, Araki Y, Harada K, Inoue M, Mitsuhashi S. Epidemiological studies of drug resistant strains in cultured fish and water. Bull Japn Soc Sci Fish 1982; 48: 1121-1127.

28. Hedges RW, Smith P, Brazil G. Resistance plasmids of aeromonads. J Gen Microbiol 1985; 131 : 2091-2095.

29. Daily OP, Joseph SW, Coolbaugh JC et al. Association of Aeromonas sobria with human infection. $J$ Clin Microbiol $1981 ; 13: 769-777$

30. Gemski P, Lazere JR, Casey T. Plasmid associated with pathogenicity and calcium dependency of Yersinia enterocolitica. Infect Immun 1980; 27: 682-685.

31. Mazaitis AJ, Maas R, Maas WK. Structure of a naturally occurring plasmid with genes for enterotoxin production and drug resistance. $J$ Bacteriol 1981 ; 145: 97-105.

32. Zink DL, Feeley JC, Wells JG et al. Plasmid-mediated tissue invasiveness in Yersinia enterocolitica. Nature 1980; 283 224-226.

33. Crosa JH. The relationship of plasmid-mediated iron transport and bacterial virulence. Annu Rev Microbiol 1984; 38 : 69 89.

34. Barja JL, Santos Y, Huq I, Colwell RR, Toranzo AE. Plasmids and factors associated with virulence in environmental isolates of Vibrio cholerae non-O1 in Bangladesh. $J$ Med Microbiol 1990; 33: 107-114.

35. Walter MA, Potter SA, Crosa JH. Iron uptake system mediated by Vibrio anguillarum plasmid pJM1. J Bacteriol 1983; 156: 880-887.

36. Valvano MA, Silver RP, Crosa JH. Occurrence of chromosomeor plasmid-mediated aerobactin iron transport systems and hemolysin production among clonal groups of human invasive strains of Escherichia coli K1. Infect Immun 1986; 52: 192-199.

37. Asao T, Kinoshita Y, Kozaki S, Uemura T, Sakaguchi G, Purification and some properties of Aeromonas hydrophila hemolysin. Infect Immun 1984; 46: 122-127.

38. Burke V, Robinson J, Beaman $\mathrm{J}$ et al. Correlation of enterotoxicity with biotype in Aeromonas spp. $J$ Clin Microbiol 1983; 18: 1196-1200. 